\title{
Phytochemical and antioxidant studies of Laurera benguelensis growing in Thailand
}

\author{
Nedeljko T. Manojlovic ${ }^{*}$, Perica J. Vasiljevic' ${ }^{2}$, Wandee Gritsanapan ${ }^{3}$, \\ Roongtawan Supabphol ${ }^{4}$ and Ivana Manojlovic ${ }^{2}$ \\ 1 Department of Pharmacy, Medical Faculty, University of Kragujevac, Kragujevac, Serbia, e-mail: ntm@kg.ac.rs, tel: +381641 137150, Fax: \\ $+38134364854$ \\ 2 Department of Biology, Faculty of Science, University of Nis, Nis, Serbia; \\ ${ }^{3}$ Department of Pharmacognosy, Faculty of Pharmacy, Mahidol University, Bangkok, Thailand, \\ ${ }^{4}$ Department of Physiology, Faculty of Medicine, Srinakarinwirote University, Thailand
}

\begin{abstract}
The aim of this study was to investigate metabolites of the lichen Laurera benguelensis. A high-performance liquid chromatographic (HPLC) method has been developed for the characterization of xanthones and anthraquinones in extracts of this lichen. Lichexanthone, secalonic acid D, norlichexanthon, parietin, emodin, teloschistin and citreorosein were detected in the lichen samples, which were collected from two places in Thailand. Components of the lichen were identified by relative retention time and spectral data. This is the first time that a detailed phytochemical analysis of the lichen L. benguelensis was reported and this paper has chemotaxonomic significance because very little has been published on the secondary metabolites present in Laurera species. Some of the metabolites were detected for the first time in the family Trypetheliaceae. The results of preliminary testing of benzene extract and its chloroform and methanol fractions showed that all samples showed a weak radical scavenging activity. The chloroform extract showed the highest antioxidant activity.
\end{abstract}

Key terms: anthraquinones, antioxidant activity, Laurera benguelensis, xanthones.

\section{INTRODUCTION}

Until now several hundred secondary metabolites, including depsides, depsidones, naphthoquinones, anthraquinones, pulvinates, chromones, and dibenzofurans, have been detected in lichens. Slow growth, and often harsh living conditions, make production of protective metabolites a necessity to lichens, and many secondary constituents are believed to serve as antigrowth, antimicrobial or antiherbivore agents (Hale, 1983; Rankovic et al. 2008). A large number of lichen species have been proven to be a source of these metabolites for food and pharmaceutical industries. Secondary lichen metabolites show a wide range of potentially useful biological activities (Yamamoto et al. 1993; Bačkor et al. 1998; Land \& Lundstrom 1998; Shahi et al. 2001). Most lichen substances with antibiotic activity are phenolic metabolites (e.g. usnic acid and the anthraquinone endocrocin) (Hale 1983; Marcano et al. 1999).

Lichens produce some characteristic anthraquinone derivatives, which have yet to be found in higher plants (Balderrama et al. 2001; Eichenberger, 2007; Nakano et al. 1972; Santesson, 1970; Søchting, 1997, Søchting 2001). Anthraquinones and xanthones are also important constituents of plants, microorganisms and insects.
They are ingredients of many medicines of plant origin since they possess a broad spectrum of biological activities, including anti-bacterial, antiinflammatory, anti-tumorous, purgative, astringent, anti-viral (Cyong et al. 1987; Muzychkina 1998) antioxidant and antifungal (Agarwal et al. 2000; Manojlovic et al. 2002, Manojlovic et al. 2008, Yen et al. 2000). Xanthone derivatives are widespread in nature, commonly occurring in a number of higher plant families, and fungi. They are of importance because of their pharmacological properties. Secalonic acid D (pale yellow crystal), a mycotoxin, was previously isolated from several food-born fungi (Raymond et al. 1977; Steyn, 1970). Secalonic acid D is also a metabolite of Penicillium oxalicum and Aspergillus aculeatus. Diverse biological activities of secalonic acid D have been reported, such as a mycotoxin towards chicken and mice embryo, an inhibitor of various isozymes of protein kinase $\mathrm{C}$ and protein kinase $\mathrm{A}$ in murine secondary palate development, as well as mouse and human cleft palatal inducing agent (Dhulipala et al. 2004; Hanumegowda et al. 2002; Wang \& Poya, 1996).

Laurera benguelensis (Müll. Arg.) Zahlbr. is a tropical microlichen (pyreno-mycete) that belongs to the family Trypetheliaceae. It is gray to light yellow in color. This lichen is distributed in tropical 
regions (Vongshewarat et al. 1999). Generally, lichens that belong to the genus Laurera have not been well investigated chemically. Until now, only 1,5,8-trihydroxy-6-methoxy-3-methyl-anthraquinone has been found in the lichen Laurera purpurina (Stensio \& Wachtmeister 1969).

The aim of this study was to made a detailed phytochemical analysis of the lichen L. benguelensis, because, until now, metabolites of this lichen have not been explored and there is a lack of information about their activities. Xanthones and anthraquinones were detected in L. benguelensis by $\mathrm{K}+$ testing and their color in UV light, with and without ammonia. The extracts of this tropical lichen were also used for antioxidant testing because recent studies showed that some natural xanthones and anthraquinones exhibit antioxidant activity (Minami et al. 1994; Yen et al. 2000).

\section{MATERIALS AND METHODS}

\section{Lichen Species Studied}

Lichen material was collected from two places in Thailand in July 2006:

1. Sample 1, yellow lichen from the Kanchanaburi Province $(10 \mathrm{~km}$ south of Erawan National Park),

2. Sample 2, gray lichen from the Kanchanaburi Province ( $25 \mathrm{~km}$ south of Erawan National Park)

The studied lichen samples were identified by Prof. Dr. Boonpagob, Department of Biology, Faculty of Science, Ramkhamhaeng University, Bangkok,Thailand as Laurera benguelensis (Müll. Arg.) Zahlbr. (yellow lichen, a voucher specimen, RU-22160) and Laurera benguelensis (Müll. Arg.) Zahlbr. (gray lichen, a voucher specimen, RU22161). The two thalli were collected from the bark of Azadirachta excelsa (Jack) Jacobs. The collected lichen material is deposited in the Ramkhamhaeng University Herbarium (RAMK).

\section{Extraction procedure}

The lichen material ( $L$. benguelensis) was air dried at room temperature $\left(26^{\circ} \mathrm{C}\right)$ for one week, after which it was ground into a uniform powder. After that, lichen material $(10 \mathrm{~g})$ was extracted with $100 \mathrm{ml}$ chloroform (1 week). The extract was filtered through Whatman filter paper No. $42(125 \mathrm{~mm})$ and concentrated using a rotary evaporator with the water bath at $40^{\circ} \mathrm{C}$. The yields of yellow and grey lichen extracts were 4.75 and $3.80 \% \mathrm{w} / \mathrm{w}$, respectively. The obtained extracts were used for HPLC analysis. The lichen benzene and methanol fractions of chloroform extract were prepared by dissolving the dried chloroform extract separately with benzene and acetone and used for antioxidant testing.

\section{HPLC studies}

All solvents used for extraction were distilled before use. High-performance liquid chromatography (HPLC) analysis was carried out on Agilent 1200 Series HPLC instrument with: C18 column (C18; $25 \mathrm{~cm} \diamond 4.6 \mathrm{~mm}, 10 \mathrm{~m}$ ) and UV Spectophotometric detector with solvent methanol-water-phosphoric acid (80:20:0.9, v/v/v). Methanol was of HPLC grade, and was purchased from Merck (Darmstadt, Germany). Phosphoric acid was analytical grade reagent. Deionized water used throughout the experiments was generated by a Milli- $Q$ academic water purification system (Milford, MA, USA). The sample injection volume was $10 \mathrm{ml}$. The flow rate was $1.0 \mathrm{ml} / \mathrm{min}$. The constituents of the chloroform extract were identified by comparison of their retention times and absorption spectra (200-600 $\mathrm{nm}$ ) to those of pure authentic samples from Sigma Company and previously isolated from lichens (Manojlovic et al. 2000, Manojlovic et al. 2005). These compounds were identified by elemental analysis and spectroscopic studies (UV, IR and ${ }^{1} \mathrm{H}$ NMR) and compared to literature data (Huneck \& Yoshimura, 1996; Manojlovic et al. 2000).

\section{Antioxidant Activity}

A stable free radical, 2,2-diphenyl-1-picrylhydrazyl (DPPH), and potassium persulfate were purchased from Sigma chemicals (St. Louis, MO, USA) and ethanol analytical grade from Merck (USA). The ABTS, 2,2'-azinobis-(3-ethylbenzothiazoline-6sulphonic acid), and Trolox, 6-hydroxy-2,5,7,8tetramethylchroman-2-carboxylic acid, were obtained from Fluka (Switzerland). The chloroform extract of L. benguelensis (sample 1, yellow lichen) and its benzene and methanolic fractions were used for determination of antioxidant activity.

\section{DPPH radical scavenging assay}

The free-radical scavenging capacity of the antioxidants was determined by $\mathrm{DPPH}$ radical scavenging assay. Briefly, DPPH was dissolved in analytical grade ethanol to obtain a $24 \mathrm{mg} / \mathrm{ml}$ solution. The DPPH solution was mixed equally with the extracts in ethanol compound in DMSO over a concentration range of $0-1.5$ and $0-0.5$ $\mathrm{mg} / \mathrm{ml}$, respectively, at ambient temperature for $30 \mathrm{~min}$. The absorbance was colorimetrically determined at $517 \mathrm{~nm}$ by a Shimadzu UV-160A spectrophotometer. The percentage of decolorization was calculated as the percentage of inhibition. Each experiment was performed in triplicate independently. Trolox was employed as positive control. The inhibition concentration at $50 \%$ 
inhibition $\left(\mathrm{IC}_{50}\right)$ was the parameter used to compare the radical scavenging activity. $\mathrm{A}$ lower $\mathrm{IC}_{50}$ meant better radical scavenging activity.

\section{Total antioxidant activity}

The total antioxidant activity of chloroform extract and its benzene and methanol fractions were determined by the colorimetric assay as Troloxequivalent antioxidant capacity (TEAC). The stable ABTS radical monocation $\left(\mathrm{ABTS}^{++}\right.$) was generated by the incubation of $7 \mathrm{mM}$ ABTS with $2.5 \mathrm{mM}$ potassium persulfate in the dark at room temperature for 12$16 \mathrm{~h}$ before use. The ABTS $^{++}$solution was diluted immediately prior to assay to an absorbance of 0.70 \pm 0.02 at $734 \mathrm{~nm}$. The $500 \mu \mathrm{l}$ diluted $\mathrm{ABTS}^{+}$solution was placed in the quartz cuvette to record the initial absorbance. Then the various concentrations of extracts or Trolox were added to each cuvette, mixed by inversion, and the absorbance at $60 \mathrm{~s}$ after addition was read exactly. Parallel blanks were performed in each assay with the appropriate solvent alone. Decolorization of blue-green color of ABTS radical cation was proportional to their antioxidant activity. The percentage inhibition compared to initial absorbance after $60 \mathrm{~s}$ was plotted as a function of sample or Trolox concentration. TEAC value was expressed as the ratio of sample and Trolox slope $\left(\mathrm{a}_{\text {sample }} / \mathrm{a}_{\text {Trolox }}\right)$. Each assay was carried out in triplicate. The higher TEAC value means the stronger antioxidant capability.

\section{RESULTS}

The present paper deals with the phytochemical analysis of extract from the species Laurera benguelensis, lichen growing on sun-exposed branches of trees in the Kanchanaburi province of Thailand. Laurera benguelensis (Mull. Arg.) Zahlbr. belongs to the family Trypetheliaceae, which is distributed widely in tropical regions. For the phytochemical analysis, a HPLC-UV method was used for the identification of xanthone and anthraquinone metabolites in L.benguelensis.

Figure 1 shows the HPLC chromatogram of the chloroform extract of L. benguelensis (sample 1 ; yellow lichens; $\mathrm{K}$ reaction is positive). The trace shows the xanthone derivatives lichexanthone and secalonic acid D and 1,8-dihydroxyanthraquinone derivatives parietin and teloschistin. The $t_{\mathrm{R}}$ values for teloschistin, secalonic acid D, lichexanthone and parietin amount to 5.92, 6.96, 16.59 and $17.44 \mathrm{~min}$, respectively. After that, the chloroform extract was separately extracted with benzene and methanol and HPLC analysis of the obtained fractions showed the presence of the anthraquinones derivatives emodin $\left(t_{\mathrm{R}}=9.76\right)$ and citreorosein $\left(t_{\mathrm{R}}=7.88\right)$.
Figure 2 shows the shapes of the absorbance spectra of the eluted compounds.

Parietin $\left(t_{\mathrm{R}}=17.44 \mathrm{~min}\right)$ was the dominant anthraquinone in the lichen examined. In nature, parietin (1,8-dihydroxy-3-methoxy-6methylanthraquinone) can be also found in plants belonging to the genera Rhamnus and Rheum, and some lichens belonging to the family Teloschistaceae. Teloschistin (1,8-dihydroxy-3-hydroxymethyl6-methoxyanthraquinone, orange needles) is a compound that has been found mainly in some lichens that belong to the family Teloschistaceae (Caloplaca, Xanthoria and Teloschistes) (Søchting, 1997, Søchting 2001). Parietin possesses some biological activities, including antibacterial and antifungal ones (Agarwal et al., 2000; Manojlovic et al. 2002).

The compounds were identified by comparison of their $t_{\mathrm{R}}$ values to the chromatogram of the standard substances. In addition, the comparison of their UV-Vis absorption spectra to those of a pure authentic sample, previously isolated from lichens, was also performed (Tab. I) The absorbance spectral data also corresponded to those in the literature (Huneck \& Yoshimura 1996; Yoshimura at al. 1994).

Figure 1 shows the HPLC chromatograms of standards and the chloroform extract of $L$. benguelensis (sample 2; gray lichen; $\mathrm{K}$ reaction is positive). The lichen was also collected from the stem bark of Azadirachta excelsa (Jack) Jacobs. The HPLC chromatogram shows norlichexanthone $\left(t_{\mathrm{R}}\right.$ $=4.66 \mathrm{~min}$ ), the most abundant compound in this extract. This compound was identified by relative retention time and spectral data. The UVspectrum of norlichexanthone exhibited characteristic absorption bands of the xanthone at $1_{\max } 205,242,312$, and 345 $\mathrm{nm}$. Norlichexanthon has previously been found in some Lecanora species (Huneck \& Yoshimura, 1996). In addition to parietin and teloschistin, two minor anthraquinones, citreorosein $\left(t_{R}=7.88\right)$ and emodin $\left(t_{R}=9.76\right)$ were identified. Emodin (1,3,8-trihyroxy-6-methylanthraquinone), a wellknown biologically active substance, is an ingredient of some pharmaceutical drugs and can be found in nature in the plants Rheum, Rhamnus, in some fungi and in some lichens belonging to the family Teloschistaceae. Citreorosein (1,3,8-trihyroxy-6hydroxymethylanthraquinone) is a compound that has been found in some lichens of the family Teloschistaceae (Muzuchina, 1998). The detection of emodin in a small amount supports previous evidence that it is an intermediate of the secalonic acid biosynthesis. This lichen contains small amounts of these metabolites and significant amounts of secalonic acid D. On the other hand, lichexanthon, which is the most abundant metabolite in the chloroform extract of yellow lichen, could not be detected in the extract of gray samples. 


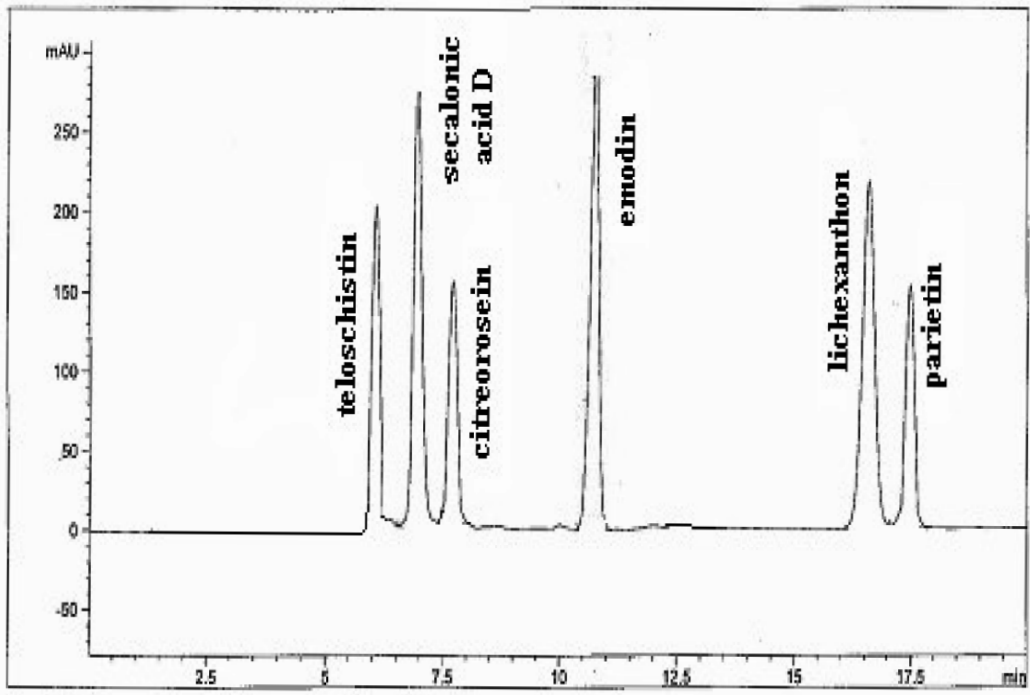

(A)

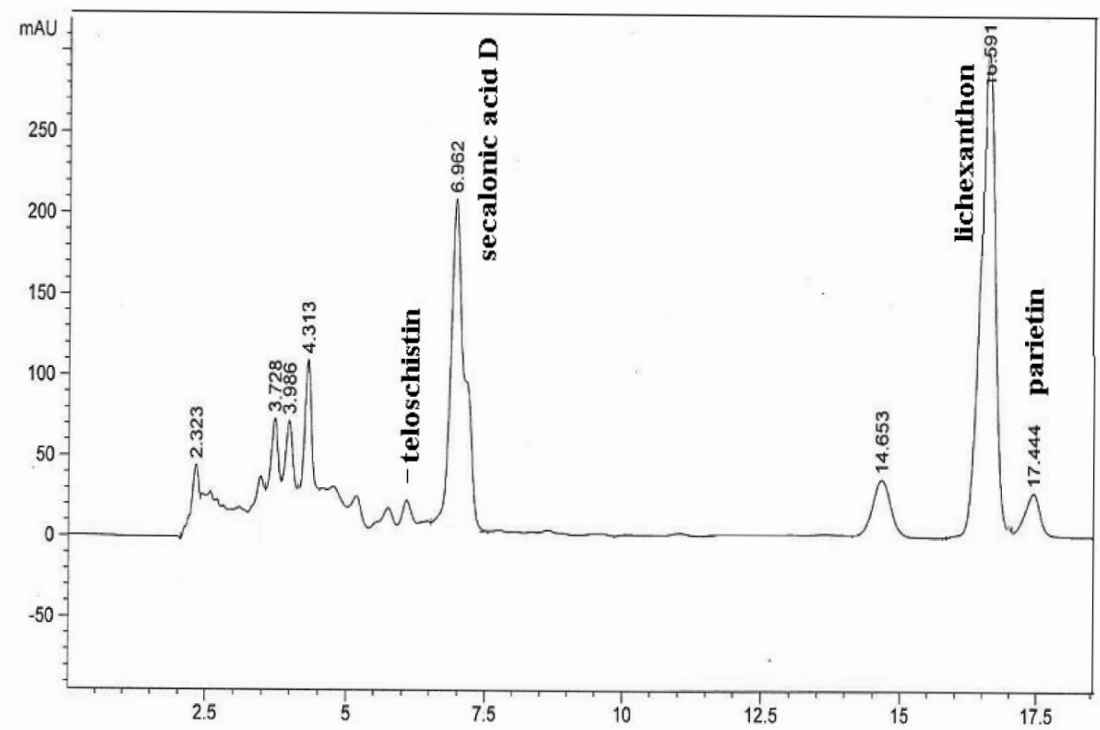

(B)

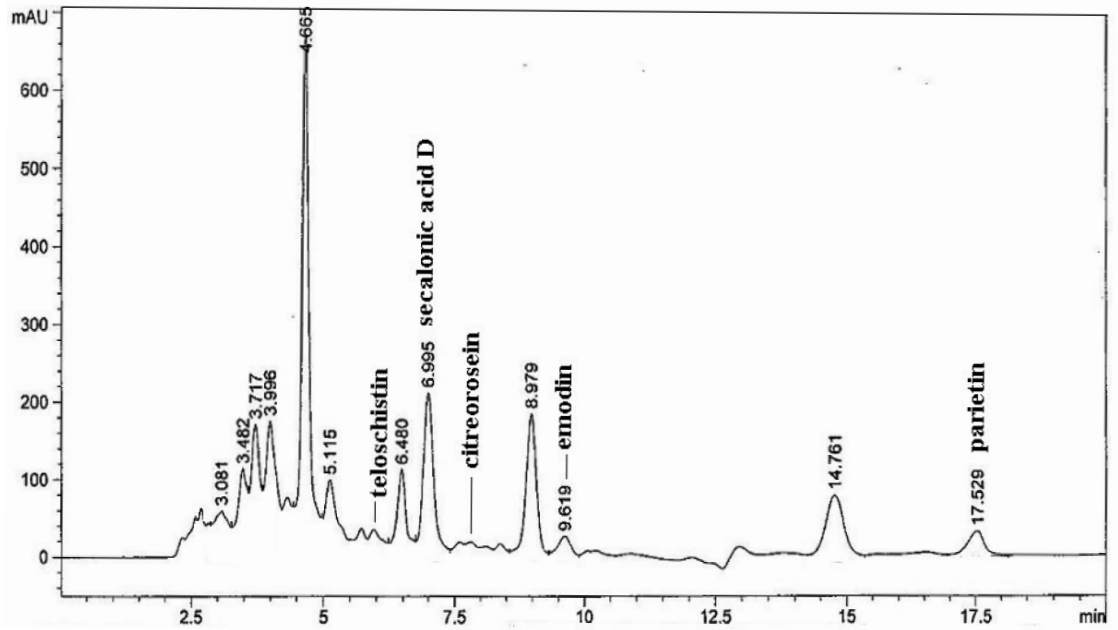

(C)

Figure 1: Representative HPLC chromatogram of (A) mixed standards, (B) Laurera benguelensis (yellow sample, Kanchanaburi, Thailand, 2006) and (C) Laurera benguelensis (grey sample, Kanchanaburi, Thailand) 

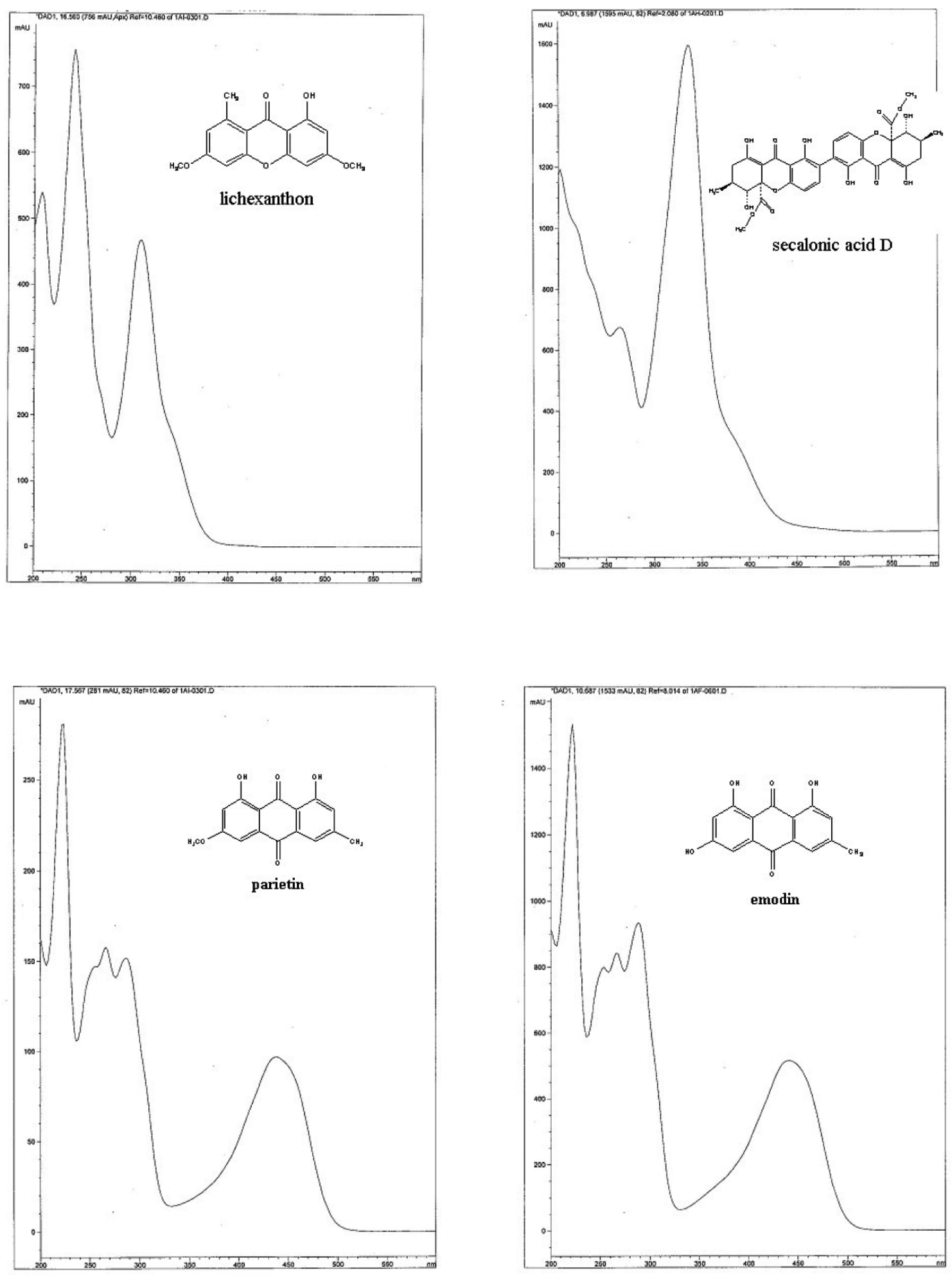

Figure 2: UV-Vis spectra of lichexanthon, secalonic acid D, parietin and emodin.The UV spectra were recorded from the HPLC chromatogram. UV traces were recorded at $254 \mathrm{~nm}$ and UV spectra from 200-600 $\mathrm{nm}$. Detailed values of absorbance maxima are given in Table 1. 
<smiles>COC(=O)[C@@]12Oc3ccc(-c4ccc5c(c4O)C(=O)C4=C(O)C[C@@H](C)[C@@H](OC)[C@]4(C(=O)OC)O5)c(O)c3C(=O)C1=C(O)C[C@@H](C)[C@@H]2O</smiles>

secalonic acid D<smiles>COc1cc(O)c2c(c1)C(=O)c1cc(C)cc(O)c1C2=O</smiles><smiles>Cc1cc(O)c2c(c1)C(=O)c1cc(O)cc(O)c1C2=O</smiles>

emodin<smiles>O=Cc1cc(O)c2c(c1)C(=O)c1c(O)cc(O)cc1C2=O</smiles>

citreorosein

Figure 3: Structures of the detected xanthone and anthraquinone metabolites.

In addition, the chloroform extract $(\mathrm{CH})$ of the lichen and its benzene (BE) and methanolic (ME) fractions were screened for their preliminary antioxidant potential using free radical scavenging and total antioxidant activities. The results of this testing are shown in Table II. Comparing these values to the results of antioxidant activity of some lichen extracts (Behera et al. 2005; Paudel et al. 2008), it can be concluded that all the tested extracts of L.benguelensis exhibited weak radical scavenging activity. On the basis of the values obtained, antioxidant activity of lichen extracts were found in following order: $\mathrm{CH}>\mathrm{BE}>\mathrm{ME}$.

\section{DISCUSSION}

The significance of this research is that it is the first time a detailed phytochemical analysis has been made of the lichen Laurera benguelensis as a source of some significant secondary metabolites (lichexanthon, secalonic acid D) whose biological activity has previously been confirmed (Ren et al 2006). The secondary chemistry is also important for the precise identification of this species. The difference in chemical composition between the yellow and gray lichen indicates the possibility of the existence of two hemotype of Laurera benguelensis. Both chemotypes contain the same anthraquinone metabolites. On the other hand, chemotype II contains norlichexanthone, which was not found in chemotype I. Chemotype I is a lichen containing lichexanthone, while Chemotype II is without lichexanthone. Although both lichen samples have similar chemical compositions, the main difference is the absence of lichexanthone in gray lichen, as well as differing amounts of anthraquinones. The yellow and gray lichens L.benguelensis contain anthraquinones, similar to those found in the Teloschistaceae, but lichexanthon, norlichexanthone and lecanolic acid D have not yet been recorded for the latter family. In addition, this paper has chemotaxonomic importance given that very little has been published on the secondary metabolites present in Laurera species (Stensio \& Wachtmeister, 1969) and some compounds were detected for first time in the family Trypetheliaceae. 
Table I

Identification of the xanthone and anthraquinone compounds by HPLC-UV

\begin{tabular}{lccc}
\hline Anthraquinone & tR (min) & $\begin{array}{c}\text { Spectral data Absorbance maxima (nm) } \\
\text { UV spectrum }\end{array}$ & Visible spectrum \\
\hline Teloschistin & 5.90 & $223,251,266,287$ & 434,455 \\
Citreorosein & 7.88 & $221,252,266,290$ & 438,458 \\
Emodin & 9,76 & $222,253,266,289$ & 436 \\
Parietin & 17.44 & $225,257,265,288$ & 433 \\
Bis-xanthone and xanthone & & & 383 \\
Norlichexanthone & 4.66 & $204,242,311,345$ & $216,236,264,337$ \\
Secalonic acid D & 6.96 & $208,243,309,341$ & \\
Lichexanthon & 16.69 & & \\
\hline
\end{tabular}

\section{Table II}

Free radical scavenging activity and total antioxidant activity of the extract and fractions from L. benguelensis

\begin{tabular}{lcc}
\hline Samples* $^{*}$ & Free radical scavenging activity $(\mathrm{mg} / \mathrm{ml})$ & Total antioxidant activity \\
\hline $\mathrm{BE}$ & $645.82+55.9$ & $0.0126+0.0013$ \\
$\mathrm{CH}$ & $432.00+21.15$ & $0.0190+0.0009$ \\
ME & $758.00+59.3$ & $0.0111+0.0010$ \\
Trolox & $5.13+0.05$ & - \\
\hline
\end{tabular}

$* \mathrm{BE}=$ benzene fraction of chloroform extract; $\mathrm{CH}=$ chloroform extract; $\mathrm{ME}=$ methanol fraction of chloroform extract

The results of preliminary tests of Laurera benguelensis chloroform extract and its benzene and methanolic fractions showed that all samples have a weak radical scavenging activity. The chloroform extract showed the strongest antioxidant activity. Further work should be focused on the isolation of pure compounds of the crude extracts of the studied lichen and investigation of their biological activity.

\section{ACKNOWLEDGEMENTS}

The authors acknowledge the financial support by the Ministry of Science and Environment of the Republic of Serbia (Grant No. 142025) and Prof. Dr. Boonpagob for determination of lichen.

\section{REFERENCE}

AGARWAL, KS, SINGH SS, VERMA S, KUMAR S (2000) Antifungal activity of anthraquinone derivatives from Rheum Emodi. J Ethnopharmacol 72: 43-46.

BAČKOR M, HUDAK J, REPČAK M, ZIEGLER W, BAČKOROVA M (1998) The influence of $\mathrm{pH}$ and lichen metabolites (Vulpinic Acid And (+) Usnic Acid ) on the growth of the lichen photobiont Trebouxia Irregularis. Lichenologist 30: 577-582.

BALDERRAMA L, BRACA A, GARCIA E, MELGAREJO M, PIZZA C, TOMMASI N (2001) Triterpenes and anthraquinones from Pioramnia Sellowai planchon in hook (Simaroubaceae). Biochem Sys Ecol 29: 331-333.

BEHERA C B, VERMA N, SONONE A, MAKHIJA U (2005) Antioxidant and antibacterial activities of lichen Usnea ghattensis in vitro. Biotechnol Lett 27: 991-995.

CYONG JC, MATSUMOTO T, ARAKAWA K, KIYOHARA H, YAMODA H, OTSUKA Y (1987) Antibacteroides Fragilis substances from Rhubarb. J Ethnopharmacol 19: 279-283.

DHULIPALA VC, HANUMEGOWDA UM, BALASUBRAMANIAN G AND REDDY CS (2004) Relevance of the palatal protein kinase A pathway to the pathogenesis of cleft palate by secalonic acid D in mice. Toxicol Appl Pharmacol 194: 270-279.

DHULIPALA, VC, WELSHONS, W V, REDDY, CS (2004) Inhibition of Human Embryonic Palatal Mesenchymal Cell Cycle by Secalonic Acid D: A Probable Mechanism of Its Cleft Palate Induction, Orthodont Craniofac Res 7: 227-236.

EICHENBERGER C, APTROOT A, HONEGGER R (2007) Three new Xanthoria species from South Africa: X. hirsuta, X. inflata and X. Doidgeae. Lichenologist 39(5): 451-458.

HALE ME (1983) The Biology Of Lichens. 3rd Ed., Edward Arnold, London, p.p. 120-137.

HANUMEGOWDA U, DHULIPALA VC, REDDY CS (2002) Mechanism of secalonic acid D-induced inhibition of transcription factor binding to cyclic AMP response element in developing murine palate, Toxicol Sci 70: 55-62.

HUNECK S, YOSHIMURA I (1996).

Identification of Lichen Substances. Berlin, Springer. p.p. 168-183.

LAND CJ, LUNDSTROM H.(1998) Inhibition of fungal growth by water extracts from the lichen Nephroma arcticum. Lichenologist 30: 259-262. 
MANOJLOVIC T N, SOLUJIC S, SUKDOLAK S (2002) Antimicrobial activity of an extract and anthraquinones from Caloplaca schaereri. Lichenologist 34: 83-85.

MANOJLOVIC T N, NOVAKOVIĆ M, STEVOVIĆ V, SOLUJIĆ S (2005) Antimicrobial activity of three Serbian Caloplaca. Pharm Biol 43(8): 1-5.

MANOJLOVIC $\mathrm{T}$ N, VASILJEVIC P, BOGDANOVICDUSANOVIC G, MANOJLOVIC I (2008) Antioxidant activity of some lichen growing in Serbia. Planta Med 74: 996-997

MARCANO V, RODRIGUEZ-ALCOCER V, MORALES MENDEZ A (1999) Occurrence of usnic acid in Usnea Laevis Nylander (lichenized ascomycetes) from the Venezuelan Andes. J Ethnopharm 66: 343-346.

MINAMI H, M KINOSHITA, FUKUYAMA Y, KODAMA M, YOSHIZAWA T, SUGIURA M, NAKAGAWA K, TAGO H (1994) Antioxidant xanthones from Garcinia subelliptica. Phytochem 36(2): 501-506.

MUZYCHKINA R A (1998) Natural Anthraquinones, Biological And Physicochemical Properties. House Phasis, Moscow

NAKANO H, KOMIYA T, SHIBATA S (1972) Anthraquinones of the lichens of Xanthoria and Caloplaca and their cultivated mycobionts. Phytochemistry 11: 3505- 3508.

PAUDEL B, BHATTARAI D H, LEE S J, HONG G S, SHIN W H, YIM H J (2008) Antioxidant activity of polar lichens from King George Island (Antarctica) Polar Biol 31: 605-608.

RANKOVIC B, MISIC M, SUKDOLAK S (2008) The antimicrobial activity of substances derived from the lichens Physcia aipolia, Umbilicaria polyphylla, Parmelia caperata and Hypogymnia physodes. World J Microb Biot 24 (7): 1239-1242.

RAYMOND A, GEORGE B, BRUNHILDE K, ARNOLD L D (1977) Secalonic acid D and F are toxic metabolites of Aspergillus aculeatus. J Org Chem 42: 352-353.

REN H, TIAN LI, GU Q, ZHU W (2006) Secalonic acid D; a cytotoxic constituent from marine lichenderived fungus Gliocladium sp. T31. Arch Pharm Res Vol 29(1): 59-63.
SANTESSON J (1970) Anthraquinones in Caloplaca. Phytochemistry 9: 2149-2166.

STENSIO E K, WACHTMEISTER (1969) 1,5,8-trihydroxy-6methoxy-3-methylantraquinone from Laurera purpurina (Nyl.) Zahlbr. Acta Chem Scand 23: 144-148.

SHAHI S K, SHUKLA A C, DIKSHIT A, UPERTI D K (2001) Broad spectrum antifungal properties of the lichen Heterodermia leucomela. Lichenologist 33: 177-179.

SøCHTING U (1997) Two Major Anthraquinone Chemosyndromes In Teloschistaceae. Bibl Lichen 68: 135-144.

SØCHTING U (2001) Chemosyndromes with chlorinated anthraquinones in the lichen genus Caloplaca. Bibl Lichen 78: 395-404.

STEYN PS (1970) The isolation, structure and absolute configuration of secalonic acid D, the toxic metabolite of Penicillium oxalicum. Tetrahedron 26: 51-57.

VONGSHEWARAT K, MCCARTHY PM, MONGKOLSUK P, BOONPAGOB K, (1999) Additions to the lichen flora of Thailand. Mycotaxon 70: 227-236

YAMAMOTO Y, MIURA Y, HIGUCHI M, KINOSHITA Y, YOSHIMURA I (1993) Using lichen tissue cultures in modern biology. Bryologist 96: 384-393.

YEN GC, DUH PD, CHUANG DY (2000) Antioxidant activity of anthraquinones and antrone. Food Chem 70: 437-441.

YOSHIMURA I, KUROKAWA T, KINOSHITA Y, YAMAMOTO Y, HUNECK S, YAMADA Y (1994) Analysis of secondary metabolites from lichen by High performance liquid chromatography with a photodiode array detector. Phytochem Anal 5: 197-205.

YOSHIMURA I, KUROKAWA T, KINOSHITA Y, YAMAMOTO Y, MIYAWAKI H (1994) Lichen substances in cultured lichens. J Hatt Bot Lab 76: 249-261.

WANG B H, POYA G M (1996) The fungal teratogen secalonic acid $D$ is an inhibitor of protein kinase $C$ and of cyclic AMP dependent protein kinase. Planta Med 62: 111-114. 